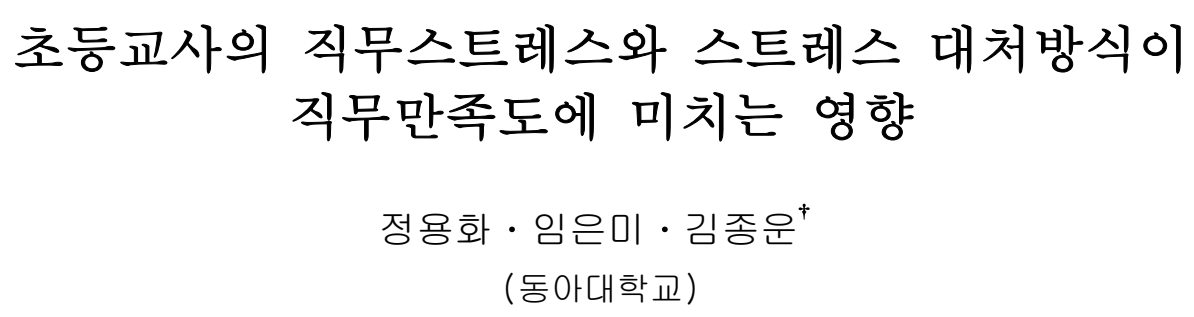

\title{
The Influences of Job Stress and Stress-Coping Style on Job Satisfaction of the Elementary School Teachers
}

\author{
Yong-Hwa JEONG $\cdot$ Eun-Mi LIM $\cdot$ Jong-Un $\mathrm{KIM}^{\dagger}$ \\ (Dong-A University)
}

\begin{abstract}
The purpose of this study was to verify the influences among job stress, stress-coping style and job satisfaction of the elementary school teachers. An objective of study is 256 elementary school teachers. After choosing 7 schools located in Busan, 283 teachers participated in this study. The measurements used in this study were the teachers' job stress scale, coping ability scale against stress, and the Korea Teacher Opinionnaire Test. The collected data were analyzed with SPSS 14.0 program. For handling data, correlations and Multiple Regression Analysis was conducted.

Major findings were summarized as follows: First, it is found that reward \& personnel management in sub-variables of job stress and control method in sub-variables of stress-coping style has significantly predicted job satisfaction level. Second, in sub-variables of job satisfaction, reward \& personnel management, control method, management system, learning establishments has significantly predicted duties, increase of specialty, human relationships, and work atmosphere, respectively. Finally, the limitation of this study and suggestion for further research are presented.
\end{abstract}

Key words : Elementary School Teacher, Job Stress, Stress-Coping Style, Job Satisfaction

\section{I. 서 론}

최근 한국교총에서 스승의 날을 맞아 전국 교 원 3천 271명에게 온라인으로 교원인식 설문조사 를 한 결과 '교사 자신이나 동료 교사들의 교직 에 대한 만족도 및 사기가 최근 1 2년간 어떻게 변화했느냐'는 질문에 $81 \%$ 가 '떨어졌다'고 응답 했다(연합뉴스, 2012년 5월 14일자). 또한 교사들
은 같은 질문에 2009년에는 55.3\%, 2010년 63.4\%, 2011년 79.5\%가 '떨어졌다'고 답한데 이어 올해까 지 4년 연속 교직 만족도 및 사기가 추락하고 있 다고 답했다. 학교 교육의 성패를 좌우하는 막중 한 책임과 함께 학교 조직에 있어 가장 중요한 역할을 담당하고 있는 교사의 심신이 건강해야 학생들이 교육목표를 달성하는 데 효과적으로 도 움을 주고 학교 조직이 제 기능을 수행할 수 있

\footnotetext{
† Corresponding author : 051-200-7077, jongun22@dau.ac.kr
} 
을 것이다. 그러나 현대를 사는 사람은 어느 조 직에서나 구성원들이 직무 스트레스를 받지 않을 수 없는 것처럼 교사 또한 여러 가지 면에서 많 은 직무 스트레스를 받고 있다.

이처럼 교사들이 행하는 활동의 대부분이 계속 적인 지적 과정을 수반하는 고도의 정신노동이라 고 볼 때, 교사들은 다른 직업에 종사하는 어떤 개인들보다 더 많은 스트레스를 경험한다고 말할 수 있다.

과도한 수업 부담과 교사에 대한 학생과 학부 모 및 사회의 가치관 변화와 각종 교권 침해, 교 사 다면평가에 대한 심리적 압박감 및 학교 간, 학급 간 줄세우기식 학업성적 비교로 인한 부담 감 등은 교사들로 하여금 점점 더 많은 직무 스 트레스에 직면하게 만들었다.

교사의 직무스트레스는 근무의욕과 사기를 저 하시키고 교사의 정신적, 신체적 건강을 손상시 킴으로써 전반적인 교육력을 약화시키는 결과를 초래하며 조직의 효율성에도 악영향을 주고 있 다. 또한 교사가 느끼는 직무 스트레스는 교사 자신들 뿐만 아니라 국가의 장래를 짊어질 학생 들에게도 직접적인 영향을 미치기 때문에 매우 중요하다(김정휘, 고흥화, 2003; 원효헌, 남인애, 2003; 이경화, 정혜영, 2009; 이희영, 정민상, 2007; Dworkin, 1987).

미국과 유럽 전역에 걸친 연구(Travers \& Cooper, 2006)에서 나타난 바로는 교사들 중에도 직업병으로서 스트레스를 인지하는 경우가 증가 하고 있다는 것이 밝혀지고 있다. 그 중에서도 어린이를 상대로 하는 교직은 타 직종의 직무 환 경보다 더 많은 스트레스 유발요인을 갖고 있어 고수준의 스트레스 직종으로 보고되었다(성병창, 2007; 여환원, 1999). Yoon(2002)의 초등학교 교사 의 스트레스와 그로 인해 나타나는 부정적인 교 사와 아동 간의 관계를 밝힌 연구에서 보면, 초 등교사가 경험하는 스트레스가 교실 내에서 교사 의 부정적인 감정표현을 증가시켜 학생들로 하여 금 교사를 부정적인 사람으로 인식하도록 만들고
이러한 인식은 다시 교사와 학생의 관계의 질을 손상시키게 된다. 결국 학생의 교육활동 및 지적. 정서적 발달에 심각한 영향을 미칠 수 있다(박태 철, 2001). 즉 교사의 직무스트레스가 장기적으로 지속 되고 누적되면 결국에는 교사 자신과 교사 가 속해 있는 조직 모두에 부정적인 영향을 미치 게 된다.

실제 교사들이 느끼는 스트레스 요인은 매우 다양하다. 교사의 직무스트레스에 미치는 유발요 인에 대해서 Wiseman, Cooner 및 Knight (1999) 는 스트레스 유발요인으로 학교 규모, 교수자료 부족, 규율문제, 교사에 대한 공적 압력 등을 들 었고, Bennett(1999)는 급료, 잡무, 전문성의 향상, 교수 학습시설, 학급운영, 교육과정 운영, 교수 학습 준비, 학교 경영의 방침, 학부모 관계 등의 구체적인 요인으로 분류하였다.

국내에서는 직무스트레스 요인을 교수활동, 연 수활동, 학급경영, 사무처리, 교원인사, 학교경영 의 여섯 가지로 보고한 연구(최인순, 2001), 직무 스트레스 요인을 성격유형별 즉 외향성, 내향성, 사고형, 감정형의 4 개 요인으로 제시한 연구(양영 모, 2000), 초등교사의 자기효능감과 사회적 지지, 직무스트레스와의 관계에서 직무스트레스 요인을 관료적 운영, 권위상실, 불화와 갈등, 낮은 대우, 과부하, 학습관리, 학생지도의 7 개의 영역으로 제 시한 연구(김윤하, 2005)가 있다.

교사들이 교육 현장에서 여러 가지 직무를 수 행하는 동안에 직무스트레스를 겪는 것은 피할 수 없는 현상이다. 중요한 것은 스트레스를 경험 하느냐 안하느냐에 있는 것이 아니라 스트레스에 직면했을 때 그것에 어떻게 대처하고 해소해 나 가느냐에 있다(Ralf \& Suhair, 2008).

직무스트레스는 원인에 따라, 강도에 따라, 지 속되는 정도에 따라 일시적일 수도 있고, 장기간 에 걸칠 수도 있으며, 그 정도가 약할 수도 있고 심할 수도 있다(홍미순, 2002; Latack, 1986).

따라서 그 원인에 맞는 스트레스 대처방식을 찾는 것이 중요하다. 대처방식을 안다면 똑같이 
직무스트레스를 받더라도 상황에 잘 대처하여 스 트레스로 인해 고통 받는 시간이 줄어들 것이고, 교육활동을 원활히 수행하여 학생들에게 질 높은 교육을 할 수 있으며, 교사 개인적으로도 직무 만족도를 높이는데 도움이 될 것이다.

아침에 등교하는 시간부터 수업을 마치는 시간 까지 온종일 아동과 함께 생활하면서 여러 교과 를 가르쳐야 하는 경우가 대부분인 초등교사에게 있어 직무스트레스에 잘 대처하여 직무만족도를 높이는 일은 교사 자신에게 뿐만 아니라 자라나 는 아동의 심신발달과 인격형성에 지대한 영향을 끼친다고 볼 수 있다.

한편 학교 조직에서 교사의 직무만족이란 교사 가 사회적, 경제적, 심리적으로 안정되고 만족한 상태에서 자발적이며 적극적으로 교육목표 달성 에 기여하려는 마음가짐과 태도라고 할 수 있다 (장한기, 강경희, 2006). 이런 능동적인 교육활동 을 통해서 개인적인 만족과 학교 교육활동의 능 률을 향상시키고 이것이 사회적 국가적으로 인정 받을 가치가 있을 때 교사의 직무만족도는 증진 된다(Ivancevich \& Metteson, 1990; Ivancevich, Matteson \& Prestin, 1982). 반면, 교사의 직무만 족도가 낮은 상태에서 교직에 종사할 경우 개인 적인 측면에서나 교육의 목표 달성 면에서 비효 율적이고 비생산적인 결과를 가져오게 된다(장한 기, 강경희, 2006; 장한기, 조영주, 2006; 박청자, 1983).

교사들의 직무만족도에 영향을 미치는 요인은 개인이나 교사집단의 기본적인 욕구와 환경적, 심리적 상황에 따라 다양하고 복잡하게 형성된 다. 교사의 직무만족도 결정요인을 보면, 국내 연 구들(류순열, 2004; 이현정, 2007)은 교사의 헌신 도, 보상, 동료관계, 인간관계, 업무 도전감 등으 로 보고하고 있으며, 국외 연구들(Billingsley, Gersten, Gillman \& Morvant, 1995; Ma \& Macmillan, 1999)에서는 교사의 직무만족도의 요 인들로는 스트레스, 역할에 대한 지침, 학교관리 자와 관련된 요인, 직에 대한 태도, 근무환경을
제시하고 있다.

교사의 직무스트레스에 관한 선행연구를 살펴 보면, 교사의 직무 스트레스의 원인에 관한 연구 (오숙희, 2006; 전택수, 1992; Cichon \& Koff, 1979; Kyriacou, 1987; Moracco \& Danford \& D'arienzo, 1982; Moracco \& McFadden, 1980)와 교사의 직무스트레스와 대처방안에 대한 연구(서 대철, 2002; 박영재, 2003; 박태철, 2001; 박현진, 2003; 이범국, 1999; 이향란, 1992; 최인순, 2001; Feitler \& Tokar, 1981; Kyriacou, 1981)가 있다.

이상의 여러 선행 연구의 결과에서 볼 수 있는 바와 같이 직무스트레스와 직무만족도 사이에는 부적 상관관계가 있다.

또한 초·중등교사의 스트레스와 직무만족도와 의 관계에 관한 연구(김기석, 1994; 여환원, 1999; 이현숙, 1993; 장한기, 강경희, 2006)에서는 학교 의 행정적 지원부분과 교사 동료와의 관계 및 업 무과다로 인한 부분에서 과다한 스트레스를 받고 있는 것으로 나타났으며, 젊은 교사들은 행정적 지원과 같은 업무처리로 인한 스트레스가 비교적 높았고 교직경력이 많은 교사들은 학교에서 중심 적 역할을 수행하면서 비교적 많은 업무로 인한 스트레스 정도가 높다고 인식하고 있었다. 또한 초등학교 교사들은 교직과 교육과정운영, 동료교 사와의 관계, 그리고 보수와 행정적 지원에서 중 등학교 교사에 비해 약간 더 높은 만족수준을 나 타낸다고 보고하였다.

윤성혜(2007)는 교사의 심리적 안녕감과 스트 레스 대처방식 및 직무만족도와의 관계에서 직무 만족도가 스트레스의 대처방식과도 정적인 관계 를 보였다. 또한 교사 생활의 한 부분인 직무에 대한 불만이 전이효과를 가져와 학생들에게도 영 향을 미친다는 점을 밝혔다.

이들 선행 연구들에서 보면, 교사의 직무스트 레스와 대처방식과의 관계에 대한 연구나 직무 스트레스와 직무만족도와의 관계에 관한 연구 등 은 비교적 활발하게 이루어지고 있는 실정이나 직무스트레스와 스트레스 대처방식이 직무만족도 
에 미치는 영향을 검증한 연구는 찾아보기 어렵 다. 특히 초등학교 교사는 여러 과목을 가르쳐야 하는 수업부담과 교수학습자료 미비 및 평가업무 의 부담, 연수내용 및 방법의 부적절성, 사무처리 로 인한 교재연구시간의 침해, 관리자의 일방적 인 의사결정 등으로 인하여 중등교사에 비해 직 무스트레스를 더 많이 받고 있는 것으로 보고되 고 있다(김봉신, 1996; 김진희, 2000).

따라서 본 연구는 초등교사의 직무스트레스와 스트레스 대처방식이 직무만족도에 미치는 영향 을 검증하고자 한다. 즉 학습시설, 동료관계, 잡 무, 보상.인사, 행정체계, 학습지도 등 직무스트레 스의 하위요인 및 증상관리방법, 통제방법, 회피 방법 등 스트레스 대처방식의 하위요인이 직무만 족도에 미치는 상대적 영향력을 검증하고자 한 다. 이를 통해 최근 교직만족도가 급격히 떨어지 고 있는 교단 현실에서 초등교사의 교직만족도를 높이기 위한 방안을 마련하는 데 필요한 기초자 료를 제공하고자 한다.

이러한 연구목적을 달성하기 위한 연구문제는 다음과 같다. 첫째, 초등교사의 직무스트레스와 스트레스 대처방식 및 직무만족도의 상관은 어떠 한가? 둘째, 초등교사의 직무스트레스와 스트레 스 대처방식이 직무만족도에 미치는 영향은 어떠 한가?

\section{II. 연구 방법}

\section{1. 연구대상}

본 연구는 부산광역시의 사하구와 북구, 해운 대구에 소재한 7 개 초등학교의 교사를 표집대상 으로 선정하여 실시하였으며, 회수된 283부의 설 문지 중에서 검사문항에 불성실하다고 판단되는 27부를 제외한 256부를 분석 대상으로 삼았다. 이 설문에 응답한 연구 대상자의 배경별 특성을 보면 <표 1 >과 같다.
<표 $1>$ 연구대상의 인구통계학적 특성 $(n=256)$

\begin{tabular}{ccrc}
\hline & 구분 & 사례수 & 비율 $(\%)$ \\
\hline \hline \multirow{2}{*}{ 성별 } & 남 & 60 & 23.4 \\
& 여 & 196 & 76.6 \\
\hline \multirow{2}{*}{ 직위 } & 부장교사 & 56 & 21.9 \\
& 교사 & 200 & 78.1 \\
\hline & 5년 미만 & 40 & 15.6 \\
교직 & 5년 15년 미만 & 99 & 38.7 \\
경력 & 15년 25년 미만 & 55 & 21.5 \\
& 25년 35년 미만 & 45 & 17.6 \\
& 35년 이상 & 17 & 6.6 \\
\hline \multirow{2}{*}{ 학교 } & 가 & 44 & 17.2 \\
급지 & 나 & 126 & 49.2 \\
& 다 & 86 & 33.6 \\
\hline \multirow{3}{*}{ 담임 } & 1,2학년 & 60 & 23.4 \\
학년 & 3,4학년 & 73 & 28.5 \\
& 5,6학년 & 90 & 35.2 \\
& 전담교사 & 33 & 12.9 \\
\hline
\end{tabular}

연구 대상자의 특성에서 성별에 의한 분포를 살펴보면, 초등학교라는 특성상 여자 교사의 비 율 $(76.6 \%)$ 이 남자 교사의 비율 $(23.4 \%)$ 보다 3 배 이 상 많았으며, 일반교사 $(78.1 \%)$ 가 부장교사 $(21.9 \%)$ 보다 훨씬 높은 비율을 차지하였다. 교직경력에 서는 5년 이상 15 년 미만의 교사의 비율이 $38.7 \%$ 로 가장 높았으며, 학교 급지에서는 나 급 지가 절반 정도 $(49.2 \%)$ 를 차지하였다. 담임 학년 에서는 1,2 학년( $23.4 \%)$ 과 3,4 학년( $28.5 \%), 5,6$ 학 년(35.2\%)이 비교적 고른 분포를 보이나 저출산 의 영향으로 저학년으로 갈수록 학급수가 줄어들 어 담임의 비율도 줄어들었으며, 전담교사의 비 율은 $12.9 \%$ 를 차지하였다.

\section{2. 측정도구}

교사의 직무스트레스와 대처방식 및 직무만족 도의 관계를 알아보기 위해 사용한 측정도구는 교사의 직무스트레스 척도, 스트레스 대처방식 척도, 직무만족도 척도의 세 가지이다.

가. 교사 직무스트레스 척도

교사의 직무스트레스를 측정하기 위하여 본 연 구에서는 이수현(2004)의 '교사의 직무스트레스 
척도'를 장연진(2008)이 수정·보완한 것을 사용하 였다. 이 척도는 점수가 높을수록 직무에 관련된 스트레스가 높은 것을 의미하고, 점수가 낮을수 록 직무스트레스를 낮게 인식하고 있음을 의미한 다.

이 척도의 내용은 학습시설, 동료관계, 잡무, 보상-인사, 행정체계, 학습지도 등 6 개의 하위 영 역으로 구성되어 있으며, Likert의 5단계 평정척 도에 의하여 '전혀 그렇지 않다', '거의 그렇지 않 다', '보통이다', '자주 그렇다', '항상 그렇다'로 구분한다. 본 연구에서 교사 직무스트레스 척도 의 신뢰도는 .91 이며, 교사 직무스트레스 척도의 문항구성 및 신뢰도는 <표 2>와 같다.

\section{<표 2> 교사 직무스트레스 척도의 문항구성 및 신뢰도}

\begin{tabular}{c|c|c}
\hline $\begin{array}{c}\text { 하위요인 } \\
\text { (문항수) }\end{array}$ & 문항 번호 & Cronbach's a \\
\hline \hline 학습시설(3) & $1,2,3$ & .78 \\
\hline 동료관계(3) & $4,5,6$ & .77 \\
\hline 잡 무(6) & $7,8,9,19,20,21$ & .82 \\
\hline 보상 · 인사(6) & $13,14,15,16,17,18$ & .82 \\
\hline 행정체계(3) & $22,23,24$ & .89 \\
\hline 학습지도(3) & $10,11,12$ & .74 \\
\hline 전체(24) & & .91 \\
\hline \multicolumn{2}{|c}{}
\end{tabular}

나. 직무스트레스 대처방식 척도

본 연구에서 직무스트레스 대처방법을 측정하 기 위하여 원용준(1997)의 스트레스 대처방법 문 항을 사용하였다. 교사의 직무스트레스 대처방법 을 증상관리방법 8 문항, 통제방법 5문항, 회피방 법 4 문항으로 구분하였으며 17문항을 Likert의 5 단계 평정척도로 하여 평정하도록 되어 있다. 증 상관리방법은 휴식이나 운동 및 여행을 통해 정 서적 안락감을 찾는 스트레스 대처방법이고, 통 제방법은 전문가, 선배, 동료교사와 의논하거나 구체적인 계획을 수립·실행을 통해 적극적이고 진취적으로 스트레스에 대처하는 방법이며, 회피 방법은 스트레스 상황을 회피하는 대처방법을 말 한다. 본 연구에서 직무스트레스 대처방식 척도
의 문항구성 및 신뢰도는 <표 3>과 같다.

\section{<표 3> 직무스트레스 대처방식 척도의 문항구성} 및 신뢰도

\begin{tabular}{c|c|c}
\hline 하위요인(문항수) & 문항 번호 & Cronbach's a \\
\hline \hline 증상관리방법(8) & $1 \sim 8$ & .72 \\
\hline 통제방법(5) & $9 \sim 13$ & .78 \\
\hline 회피방법(4) & $14 \sim 17$ & .80 \\
\hline 전체(17) & $1 \sim 17$ & \\
\hline
\end{tabular}

다. 직무만족도 척도

초등학교 교사의 직무만족을 측정하기 위한 검 사지를 대한교육연합회의 전성연(1982)이 개발한 교사 직무만족 척도(Korea Teacher Opinionnaire: $\mathrm{KTO})$ 를 사용하였다. 직무만족도 검사는 7 개 하 위요인 40 문항으로 구성되어 있으며, 문항반응 양식은 Likert의 5단계 평정척도로 구성되어 있 다. 본 연구에서 직무만족도 척도의 Cronbach's $a$ 에 의한 전체 신뢰도는 .81 이며, 직무만족도 척 도의 문항구성 및 신뢰도는 <표 $4>$ 와 같다.

<표 4> 직무만족도 척도의 문항구성 및 신뢰도

\begin{tabular}{c|c|c}
\hline $\begin{array}{c}\text { 하위요인 } \\
\text { (문항수) }\end{array}$ & 문항 번호 & Cronbach's a \\
\hline \hline 인간관계(7) & $1,2,3,4,5,6,7$ & .72 \\
\hline 직 무(8) & $8^{*}, 9,10,11,12,13,14^{*}, 15^{*}$ & .74 \\
\hline 근무환경(5) & $16,17,18,19^{*}, 20^{*}$ & .74 \\
\hline 보 상(5) & $21,22^{*}, 23,24^{*}, 25$ & .75 \\
\hline 전문성신장(5) & $26^{*}, 27,28,29,30$ & .76 \\
\hline 행정지원(5) & $31,32,33^{*}, 34,35$ & .74 \\
\hline 인정지위(5) & $36,27,38^{*}, 39,40^{*}$ & .74 \\
\hline 전체(40) & & .81 \\
\hline
\end{tabular}

*표시 문항은 역채점 문항임

\section{3. 자료수집}

설문조사는 본 연구자의 학교를 포함한 부산광 역시 사하구의 4 개 학교와 북구의 2 개 학교, 해운 대구의 1 개 학교의 총 7 개 초등학교의 교사 283 명에게 의뢰하여 회수하는 방법으로 실시하였다. 


\section{4. 자료처리}

본 연구의 목적은 초등교사의 직무스트레스 정 도에 따른 스트레스 대처방식과 직무만족도를 알 아보고, 그들 간의 상관을 분석하는데 있었다. 이 를 위하여 수집한 자료는 본 연구에서 설정한 연 구문제를 분석하기 위해 통계프로그램인 SPSS 14.0 을 사용하였다.

초등교사의 직무스트레스와 스트레스 대처방식 및 직무만족도의 상관을 알아보기 위한 pearson 적률상관계수를, 그리고 초등교사의 직무 스트레 스와 스트레스 대처방식이 직무만족도에 미치는
영향을 알아보기 위해 중다회귀분석(Multiple Regression Analysis)을 사용하여 분석하였다.

\section{III. 연구 결과}

1. 초등교사의 직무스트레스와 스트레스 대 처방식, 직무만족도 간의 상관

초등교사의 직무스트레스와 스트레스 대처방 식, 직무만족도간의 상관을 알아보기 위하여 각 하위요인별로 상관관계를 분석한 결과는 다음 $<$ 표 $5>$ 와 같다.

<표 5> 교사 직무스트레스와 스트레스 대처방법, 직무만족도간의 상관

\begin{tabular}{|c|c|c|c|c|c|c|c|c|c|c|c|c|c|c|c|}
\hline 변인 & 1 & 2 & 3 & 4 & 5 & 6 & 7 & 8 & 9 & 10 & 11 & 12 & 13 & 14 & 15 \\
\hline 2 & $.446 * *$ & & & & & & & & & & & & & & \\
\hline 3 & $.384 * *$ & $.409 * *$ & & & & & & & & & & & & & \\
\hline 4 & $.415 * *$ & $.543 * *$ & $.614 * *$ & & & & & & & & & & & & \\
\hline 5 & $.296 * *$ & $.517 * *$ & $.565 * *$ & $.733 * *$ & & & & & & & & & & & \\
\hline 6 & $.289 * *$ & $.404 * *$ & $.564 * *$ & $.506 * *$ & $.449 * *$ & & & & & & & & & & \\
\hline 7 & $.295 * *$ & $.242 * *$ & $.351 * *$ & $.259 * *$ & $.263 * *$ & $.175 * *$ & & & & & & & & & \\
\hline 8 & $.196 * *$ & $.208 * *$ & $.178 * *$ & $.132 *$ & .116 & .045 & $.382 * *$ & & & & & & & & \\
\hline 9 & .116 & $.130 *$ & $.162 *$ & .033 & .102 & .027 & $.336 * *$ & $.360 * *$ & & & & & & & \\
\hline 10 & -.047 & $-.236 * *$ & $-.147 *$ & $-.339 * *$ & $-.376 * *$ & $-.230 * *$ & $.133 *$ & $.318 * *$ & $.188 * *$ & & & & & & \\
\hline 11 & $-.333 * *$ & $-.257 * *$ & $-.421 * *$ & $-.476 * *$ & $-.370 * *$ & $-.387 * *$ & $-.222 * *$ & -.066 & -.039 & $364 * *$ & & & & & \\
\hline 12 & $-.469 * *$ & $-.383 * *$ & $-.330 * *$ & $-.450 * *$ & $-.431 * *$ & $-.244 * *$ & $-.157 *$ & .022 & $.129 *$ & $405 * *$ & $390 * *$ & & & & \\
\hline 13 & $-.254 * *$ & $-.197 * *$ & $-.220 * *$ & $-.373 * *$ & $-.337 * *$ & $-.125 *$ & .004 & .102 & .061 & $368 * *$ & $300 * *$ & $451 * *$ & & & \\
\hline 14 & .091 & .032 & -.020 & -.055 & $-.124 *$ & $-.157 *$ & .079 & $.304 * *$ & $.170 * *$ & $393 * *$ & $196 * *$ & $202 * *$ & $279 * *$ & & \\
\hline 15 & -.109 & $-.248 * *$ & $-.265 * *$ & $-.433 * *$ & $-424 * *$ & $-.198 * *$ & -.077 & $.210 * *$ & $.156 *$ & $550 * *$ & $439 * *$ & $401 * *$ & $421 * *$ & $.305 * *$ & \\
\hline 16 & -.106 & $-.252 * *$ & $-.260 * *$ & $-.425 * *$ & $-.416 * *$ & $-.305 * *$ & -.009 & $.166 * *$ & $.174 * *$ & $481 * *$ & $416 * *$ & $354 * *$ & $454 * *$ & $.274 * *$ & $.482 * *$ \\
\hline $\mathrm{M}$ & 7.031 & 6.352 & 15.500 & 13.715 & 6.891 & 6.734 & 21.758 & 13.961 & 11.856 & 21.324 & 24.695 & 16.477 & 15.125 & 16.555 & 15.926 \\
\hline SD & 2.613 & 2.499 & 4.501 & 4.7963 & 2.938 & 2.2682 & 4.725 & 3.405 & 2.986 & 3979 & 4.010 & 3.4288 & 2.923 & 2.970 & 3.0561 \\
\hline skew & .538 & .430 & .159 & .437 & .460 & .318 & .131 & .002 & -.030 & .099 & .035 & .018 & .245 & .251 & .004 \\
\hline kurtosis & -.301 & -.521 & -.844 & -.315 & -.528 & -.610 & .016 & .067 & -.133 & .236 & .017 & -.384 & -.150 & .209 & -.224 \\
\hline
\end{tabular}

주. 1. 학습시설 2. 동료관계 3. 잡무 4. 보상.인사 5. 행정체계 6. 학습지도 7. 증상관리방법

8. 통제방법 9. 회피방법 10. 인간관계 11. 직무 12. 근무환경 13. 보상 14. 전문성신장 15. 행정지원 16.인 정 지위

첫째, 직무스트레스와 스트레스 대처방식의 상 관을 보면 직무 스트레스의 하위요인인 학습시설 과 잡무는 스트레스 대처방식의 하위요인인 증상 관리방법, 통제방법 $(\mathrm{p}<.01)$ 에서, 행정체계와 학습
지도는 증상관리방법 $(\mathrm{p}<.01)$ 과 유의한 정적상관이 있는 것으로 나타났다. 동료관계는 증상관리방법, 통제방법 $(\mathrm{p}<.01)$, 회피방법 $(\mathrm{p}<.05)$ 에서, 보상.인사 는 증상관리방법 $(\mathrm{p}<.01)$ 과 통제방법 $(\mathrm{p}<.05)$ 과 유 
의미한 정적상관이 있는 것으로 나타났다. 둘째, 직무스트레스와 직무만족도와의 상관을 알아보면 직무스트레스의 하위요인인 학습시설은 직무만족 도의 하위요인인 직무, 근무환경, 보상 $(\mathrm{p}<.01)$ 과 유의미한 부적상관이 있는 것으로 나타났으며, 동료관계는 인간관계, 직무, 근무환경, 보상, 행정 지원 $(\mathrm{p}<.01), \quad$ 인정지위 $(\mathrm{p}<.05)$ 와 유의미한 부적상 관이 있는 것으로 나타났다. 잡무는 직무, 근무환 경, 보상, 행정지원, 인정지위 $(\mathrm{p}<.01)$, 인간관계 $(\mathrm{p}<.05)$ 와 부적상관이 있었다. 보상.인사는 전문성 신장을 제외한 인간관계, 직무, 근무환경, 보상, 행정지원, 인정지위 $(\mathrm{p}<.01)$ 에서, 행정체계는

인간관계, 직무, 근무환경, 보상, 행정지원, 인 정지위 $(\mathrm{p}<.01)$ 에서, 행정체계는 인간관계, 직무, 근무환경, 보상, 행정지원, 인정지위 $(\mathrm{p}<.01)$, 전문 성 신장 $(\mathrm{p}<.05)$ 과 유의미한 부적상관이 있었다. 학습지도는 인간관계, 직무, 근무환경, 행정지원, 인정지위 $(\mathrm{p}<.01)$, 보상과 전문성 신장 $(\mathrm{p}<.05)$ 과 부 적상관이 있는 것으로 나타났다.

셋째, 스트레스 대처방식인과 직무만족도의 상 관을 살펴보면 증상관리방법은 인간관계 $(\mathrm{p}<.05)$ 와 유의미한 정적 상관을, 직무 $(\mathrm{p}<.01)$, 근무환경 $(\mathrm{p}<.01)$ 과는 유의미한 부적상관이 있었으며, 직무 만족도의 나머지 하위요인들과는 유의미한 상관
이 없는 것으로 나타났다. 통제방법은 인간관계, 전문성 신장, 행정지원, 인정지위 $(\mathrm{p}<.01)$ 와 유의미 한 정적상관이 있었으며, 회피방법은 인간관계, 전문성 신장, 인정지위 $(\mathrm{p}<.01)$, 근무환경, 행정지 원 $(\mathrm{p}<.05)$ 과 유의미한 정적상관이 있었다.

\section{2. 초등교사의 직무스트레스와 스트레스 대 처방식이 직무만족도에 미치는 영향}

중다회귀분석을 실시하기 전에 먼저 독립변수 들 간의 다중공선성을 측정하기 위하여 공차 (tolerance)와 분산팽창계수(variance inflation factor: VIF)를 알아본 결과, 공차와 VIF가 1에 근 접하고 VIF가 10에 훨씬 못 미쳤으며, 산점도를 통해 확인한 결과 자료의 이상치 또한 없는 것으 로 나타났다. 따라서 이후 분석들에서 변인들 간 의 다중 공선성은 문제가 없음을 확인하였다. 잔 차간의 상호 독립성에 대한 가정을 확인하기 위 해 Durbin-Watson 통계값을 확인한 결과 2.132로 나타나 상호 독립적임이 확인되었다.

초등교사의 직무스트레스 및 스트레스 대처방 식이 교직만족도에 미치는 영향과 상대적 설명력 을 알아보기 위해 단계선택법을 사용한 중다회귀 분석을 실시하였으며, 그 결과는 <표 6>과 같다.

<표 6> 초등교사 직무스트레스와 스트레스 대처방식이 직무만족도에 미치는 영향과 상대적 설명력

\begin{tabular}{ccrrrrrr}
\hline 종속변수 & 독립변수 & $B$ & $\beta$ & $t$ & $R^{2}$ & $\Delta R^{2}$ & $F$ \\
\hline \hline & (상수) & 131.456 & & & & & \\
& 보상 - 인사 & -1.061 & -.305 & $-4.150^{* * *}$ & .289 & & $103.598^{* * *}$ \\
& 통제방법 & 1.321 & .270 & $5.250^{* * *}$ & .375 & .086 & $76.049^{* * *}$ \\
& 핵무멍체계족도 & -1.761 & -.311 & $-4.427^{* * *}$ & .413 & .038 & $59.286^{* * *}$ \\
& 회피방법 & .742 & .133 & $2.606^{*}$ & .427 & .014 & $46.873^{* * *}$ \\
& 학습시설 & -.689 & -.108 & $-2.043^{*}$ & .436 & .009 & $38.806^{* * *}$ \\
\hline
\end{tabular}

${ }^{*} \mathrm{p}<.05,{ }^{* * *} \mathrm{p}<.001$

분석결과, 보상·인사, 통제방법, 행정체계, 회피 방법, 학습시설은 초등교사의 직무만족도에 영향 을 미치는 변수로 나타났다. 즉 보상인사가공정 하고 합리적일수록, 전문가, 선배, 동료교사와 의
논하거나 구체적인 계획을 수립.실행을 통해 적 극적이고 진취적으로 스트레스에 대처할수록, 행 정체계가 민주적이고 합리적일수록 초등교사의 직무만족도가 높은 것으로 나타났다. 이에 비해, 
직무스트레스의 하위요인 중 동료관계, 잡무, 학 습지도와 스트레스 대처방식의 하위요인인 휴식 이나 운동을 통한 증상관리방법은 영향을 미치지 않는 것으로 나타났다.

이들 변수들은 초등교사의 직무만족도를 $43.6 \%$ 정도 설명해 주는데, 보상.인사는 $28.9 \%$ 로 가장 많은 설명력을 지니며, 여기에 통제방법이 첨가됨으로써 설명력이 $8.6 \%$ 가 증가하여 $37.5 \%$ 의 설명력을 가지며, 행정체계, 회피방법, 학습시 설이 첨가될 경우에는 $6.1 \%$ 증가하여 전체 $43.6 \%$ 의 설명력을 가진다. 또한 $\mathrm{F}$ 값 모두 $\mathrm{p}<.001$ 수준에서 유의한 것으로 나타나 위의 회귀모형이 적합하다는 것을 보여준다.

초등교사의 직무만족도에 영향을 미치는 독립 변수들에 대한 상대적 설명력에서는 보상.인사, 통제방법, 행정체계, 회피방법, 학습지도 순으로 많은 영향을 미치는 것으로 나타났으며, 그 중에 서도 보상인사가 가장 영향력 있는 변수로 나타 났다.

\section{3. 초등교사의 직무스트레스와 스트레스 대 처방식이 직무만족도의 하위요인에 미치 는 영향}

직무스트레스에 대한 분석에서와 마찬가지로 다중공선성의 위협이 없는 것으로 확인되었고, 자료의 이상치 또한 발견되지 않았으며, DurbinWatson 통계값을 확인한 결과 2.023로 나타나 상 호 독립적임이 확인되었다.

초등교사의 직무스트레스 및 스트레스 대처방 식이 교직만족도의 하위요인에 미치는 영향과 상 대적 설명력을 알아보기 위해 단계선택법을 사용 한 중다회귀분석을 실시하였으며, 그 결과는 <표 $7>$ 과 같다.

분석결과, 먼저 행정체계, 통제방법, 회피방법, 동료관계가 초등교사의 직무만족도 하위요인 중 인간관계에 영향을 미치는 변수로 나타났다. 즉 행정체계가 민주적이고 합리적일수록, 전문가, 선
배, 동료교사와 의논하거나 구체적인 계획을 수 립·실행을 통해 적극적이고 진취적으로 스트레스 에 대처할수록 인간관계의 직무만족도가 높은 것 으로 나타났다. 이들 변수들은 초등교사 인간관 계의 직무만족도를 $29.9 \%$ 정도 설명해 주는데, 행정체계는 $13.9 \%$ 로 가장 많은 설명력을 지니며, 여기에 통제방법이 첨가됨으로써 설명력이 $13.3 \%$ 가 증가하여 $27.2 \%$ 의 설명력을 가지며, 회피방법 과 동료관계가 첨가될 경우에는 $2.7 \%$ 증가하여 전체 $29.9 \%$ 의 설명력을 가진다.

초등교사의 직무만족도의 하위요인인 직무에는 보상인사, 학습지도, 학습시설이 영향을 미치는 것으로 나타났다. 즉 보상인사가 공정하고 합리 적일수록, 학습지도에 있어 교재연구시간이 확보 되고 재량권이 많이 주어질수록, 학습시설이 잘 갖추어져 있을수록 직무의 만족도가 높은 것으로 나타났다. 이들 변수들은 초등교사 직무의 만족 도를 $28.0 \%$ 정도 설명해 주는데, 보상인사는 $23.4 \%$ 로 가장 많은 설명력을 가지는 것으로 나타 났다.

다음으로 초등교사의 직무만족도의 하위요인인 근무환경에는 학습시설, 행정체계, 회피방법이 영 향을 미치는 것으로 나타났다. 즉 학습시설이 잘 갖추어져 있을수록, 행정체계가 민주적이고 합리 적일수록, 열악한 근무상황을 회피할수록 근무환 경의 만족도가 높은 것으로 나타났다. 이들 변수 들은 초등교사 근무환경의 만족도를 $35.7 \%$ 정도 설명해 주는데, 학습시설은 $22.4 \%$ 로 가장 많은 설명력을 가지는 것으로 나타났다.

초등교사의 직무만족도의 하위요인인 보상에는 보상인사, 통제방법, 학습시설이 영향을 미치는 것으로 나타났다. 이들 변수들은 초등교사 보상 의 만족도를 $17.1 \%$ 정도 설명해 주는데, 보상.인 사가 $12.5 \%$ 로 가장 많은 설명력을 가지는 것으로 나타났다.

또한 초등교사의 직무만족도의 하위요인인 전 문성신장에는 통제방법과 학습시설이 영향을 미 치는 것으로 나타났다. 이들 변수들은 초등교사 
<표 7> 초등교사 직무스트레스와 스트레스 대처방식이 직무만족도의 하위요인에 미치는 영향과 상대 적 설명력

\begin{tabular}{|c|c|c|c|c|c|c|c|}
\hline 종속변수 & 독립변수 & $B$ & $\beta$ & $t$ & $R^{2}$ & $\Delta R^{2}$ & $F$ \\
\hline \multirow{5}{*}{ 인간관계 } & "(상수) & 18.030 & & & & & \\
\hline & 행정체계 & -.538 & -.358 & $-5.915^{\star * *}$ & .139 & & $42.730^{* * *}$ \\
\hline & 통제방법 & .438 & .341 & $6.102^{* * *}$ & .272 & .133 & $49.238^{\star * *}$ \\
\hline & 회피방법 & .196 & .133 & $2.402^{* * *}$ & .286 & .014 & $35.123^{* * *}$ \\
\hline & 동료관계 & -.236 & -.134 & $-2.186^{* * *}$ & .299 & .013 & $27.915^{* * *}$ \\
\hline \multirow{4}{*}{ 직무 } & (상수) & 32.175 & & & & & \\
\hline & 보상 - 인사 & -.275 & -.331 & $-5.151^{* * *}$ & .234 & & $80.765^{\star * *}$ \\
\hline & 학습지도 & -.323 & -.185 & $-3.011^{* *}$ & .263 & .029 & $47.013^{* * *}$ \\
\hline & 학습시설 & -.220 & -.143 & $-.2 .486^{*}$ & .280 & .017 & $34.018^{* * *}$ \\
\hline \multirow{4}{*}{ 근무환경 } & (상수) & 20.050 & & & & & \\
\hline & 학습시설 & -.523 & -.397 & -7.634 & .224 & & $76.198^{* * *}$ \\
\hline & 행정체계 & -.387 & -.332 & -6.382 & .315 & .091 & $60.443^{* * *}$ \\
\hline & 회피방법 & .236 & .206 & 4.127 & .357 & .042 & $48.429^{* * *}$ \\
\hline \multirow{4}{*}{ 보상 } & (상수) & 16.743 & & & & & \\
\hline & 보상 - 인사 & -.192 & -.320 & -5.233 & .125 & & $38.730^{* * *}$ \\
\hline & 통제방법 & .157 & .184 & 3.236 & .152 & .027 & $24.140^{* * *}$ \\
\hline & 학습시설 & -.166 & -.150 & -2.447 & .171 & .019 & $18.388^{* * *}$ \\
\hline \multirow{3}{*}{ 전문성신장 } & (상수) & 14.090 & & & & & \\
\hline & 통제방법 & .277 & .316 & 5.481 & .094 & & $27.545^{* * *}$ \\
\hline & 학습지도 & -.211 & -.164 & -2.840 & .120 & .027 & $18.169^{* * *}$ \\
\hline \multirow{5}{*}{ 행정지원 } & (상수) & 15.718 & & & & & \\
\hline & 보상 - 인사 & -.166 & -.260 & $-3.386^{* *}$ & .173 & & $56.208^{* * *}$ \\
\hline & 통제방법 & .207 & .229 & $4.108^{* * *}$ & .240 & .067 & $42.337^{* * *}$ \\
\hline & 행정체계 & -.275 & -.262 & $-3.414^{* *}$ & .268 & .028 & $32.588^{* * *}$ \\
\hline & 회피방법 & .115 & .111 & $1.996^{*}$ & .279 & .011 & $25.710^{* * *}$ \\
\hline \multirow{5}{*}{ 인정지위 } & (상수) & 17.621 & & & & & \\
\hline & 보상-인사 & -.196 & -.275 & $-3.569 * * *$ & .185 & & $61.210^{* * *}$ \\
\hline & 통제방법 & .162 & .160 & $2.842^{* *}$ & .226 & .040 & $39.045^{* * *}$ \\
\hline & 행정체계 & -.298 & -.253 & $-3.287^{* *}$ & .251 & .026 & $29.866^{* * *}$ \\
\hline & 회피방법 & .160 & .139 & $2.470^{*}$ & .268 & .017 & $24.353^{* * *}$ \\
\hline
\end{tabular}

${ }^{*} \mathrm{p}<.05,{ }^{* *} \mathrm{p}<.01,{ }^{* * *} \mathrm{p}<.001$

전문성신장의 만족도를 $12.0 \%$ 정도 설명해 주는 데, 통제방법이 $9.4 \%$ 로 가장 많은 설명력을 가지 는 것으로 나타났다.

초등교사의 직무만족도의 하위요인인 행정지원 은 보상.인사, 통제방법, 행정체계, 회피방법이 영 향을 미치는 것으로 나타났다. 이들 변수들은 초 등교사 행정지원의 만족도를 $27.9 \%$ 정도 설명해 주는데, 보상.인사가 $17.3 \%$ 로 가장 많은 설명력을 가지는 것으로 나타났다.

끝으로 초등교사의 직무만족도의 하위요인인
인정지위에는 보상·인사, 통제방법, 행정체계, 회 피방법이 영향을 미치는 것으로 나타났다. 이들 변수들은 초등교사 인정지위의 만족도를 $26.8 \%$ 정도 설명해 주는데, 보상.인사가 $18.5 \%$ 로 가장 많은 설명력을 가지는 것으로 나타났다.

\section{IV. 논의 및 제언}

본 연구는 초등교사의 직무스트레스와 대처방 
식 및 직무만족도의 관계를 알아보기 위한 것으 로, 연구의 주요 결과를 연구문제별로 논의해보 면 다음과 같다.

첫째, 초등교사의 직무스트레스와 스트레스 대 처방식 및 직무만족도의 상관에서는 각 하위요인 들 간에 부분적으로 유의미한 상관이 있는 것으 로 나타났다.

직무스트레스와 직무만족도와의 상관에서는 직 무 스트레스의 하위요인인 동료관계, 잡무, 보상. 인사는 직무만족도의 하위요인인 인간관계, 직무, 근무환경, 보상, 행정지원, 인정지위와 부적상관 이 있었다. 또한 직무 스트레스의 하위 요인인 행정체계와 학습지도는 직무만족도의 모든 하위 요인과 부적상관이 있었다. 그러나 직무 스트레 스의 하위요인인 학습시설과 직무만족도의 하위 요인인 전문성 신장은 다른 하위요인과 가장 상 관이 적게 나타났다. 이 결과는 여러 선행 연구 (신종학, 1995; 여환원, 1999; 이현숙, 1993; 정성 훈, 2007; Beehr, 1976; Jackson, 1983; Kavanah, Hurst \& Rose, 1981)에서 직무스트레스는 직무만 족도와 유의미한 부적 상관이 있고 스트레스 대 처방식은 직무만족도와 유의미한 정적 상관이 있 다는 보고된 것과 일치한다.

둘째, 초등교사의 직무스트레스와 스트레스 대 처방식이 직무만족도에 미치는 영향에 대하여 알 아본 결과, 보상.인사, 통제방법, 행정체계, 회피 방법, 학습시설은 초등교사의 직무만족도에 영향 을 미치는 변수로 나타났다.

이는 보상인사가 직무만족도에 가장 큰 설명 력을 보여 교사들에 대한 객관적이고 공정한 보 상인사 정책의 수립.시행이 필요하다는 점을 알 수 있다. 2008년부터 시행된 교사 다면평가는 동 료교사 평가가 $30 \%$, 교장 $40 \%$, 교감 $30 \%$ 로 구성 되어 있는데 여전히 관리자의 평정 점수가 높아 객관성이 공정성을 확보하기가 어렵다고 생각된 다. 따라서 단계적으로 동료교사 평가 비율을 5 $0 \sim 60 \%$ 까지 확대하여 객관성과 공정성을 확보하 는 방안을 모색할 필요가 있다.
다음으로 증상대처방법, 통제방법, 회피방법의 스트레스 대처방식 중에서 통제방법을 사용할 경 우 직무만족도가 높다는 것을 알 수 있다. 이는 휴식이나 운동 및 여행을 통해 정서적 안락감을 찾으려는 증상관리방법보다 전문가, 선배, 동료교 사의 자문을 구하거나 초등교사 자신의 부족한 부분을 극복하기 위한 구체적인 계획을 수립하고 실행하는 통제방법이 보다 더 직무만족도에 큰 영향을 끼친다. 이를 위해서는 각 교육지원청별 각 분야 전문가를 자문단으로 하는 전문가 그룹 의 교육활동지원단 활동을 활성화할 필요가 있 다.

셋째, 초등교사의 직무만족도의 하위요인인 인 간관계에는 행정체계와 통제방법이, 직무에는 보 상.인사가, 근무환경에는 학습시설이, 보상에는 보상인사가, 전문성신장에는 통제방법이, 행정지 원에는 보상.인사가, 인정지위에는 보상-인사가 가 장 많은 설명력을 가지는 것으로 나타났다.

위에서 나타난 결과와 같이 보상.인사가 직무 만족도 전체 및 하위요인의 대부분에서 가장 큰 설명력을 보이고 있다. 보상.인사는 승진에 필요 한 근무평정뿐만 아니라 담임배정, 학교 전보시 점수, 성과급 지급 등에 다양하게 반영되고 있다. 특히 중등교사에 비해 초등교사는 전담교사의 비 율보다 담임교사의 비율이 훨씬 높아 학년배정에 있어 보상인사가 더 큰 영향을 미친다고 생각된 다. 따라서 학년배정 원칙을 공정하게 세워 시행 하는지에 대한 교육청 차원의 관리가 필요하다. 그리고 모든 초등교사가 승진을 하기를 원하지 않기 때문에 보상인사를 승진을 위한 근무평정 점수 부여와 함께 승진을 원하지 않는 초등교사 에게는 해외연수기회 부여, 교사 연구년제 우선 배정 등에 활용하는 방안도 검토할 필요가 있을 것으로 판단된다.

직무만족도의 하위요인에서 직무스트레스의 하 위요인인 보상인사가 가장 많은 설명력을 보였 으며, 통제방법도 인간관계, 보상, 전문성신장, 행 정지원, 인정지위에서 보상.인사에 이어 많은 설 
명력을 가지는 것으로 나타났다. 이는 동료교사 와 의논하거나 구체적인 계획을 수립·실행을 통 해 적극적이고 진취적으로 스트레스에 대처할수 록 직무만족도가 높다는 것을 의미한다. 이는 신 규교사뿐만 아니라 중견교사를 위한 교사효율성 훈련(teacher's effective training)과 같은 프로그 램을 개발하여 실시함으로써 교사들의 스트레스 대처방식 중 통제방법 영역의 능력 향상을 도모 할 필요가 있음을 시사한다.

또한 초등교사는 중등교사에 비해 같은 교육대 학교 출신 교사들이 대부분이다. 결국 선·후배교 사가 동문 선·후배인 경우가 대부분이기 때문에 인간관계에서 수평적인 관계보다는 수직적인 관 계가 형성된 경우가 많다. 그리고 같은 학교에 전보되면 4년 정도 같이 근무해야 하고 동학년이 되면 같은 학년에서 1 년 동안 생활해야 한다. 이 로 인하여 소통의 흐름이 경직되어 선·후배간 갈 등이 빚어져 스트레스를 경험할 수 있다. 따라서 한 학기 1 회 이상 인간관계 훈련이나 의사소통 훈련, 웃음치료, 교직원 연수 등을 계획하여 실행 할 수 있도록 시도 교육청 차원의 지침이나 재정 적, 행정적 지원 방안을 마련할 필요가 있다.

이와 같은 논의를 바탕으로 본 연구의 제한점 과 후속연구를 위한 제언은 다음과 같다.

첫째, 직무만족도에 긍정적 또는 부정적으로 영향을 미치는 다양한 변인들에 대한 추후연구가 필요하다. 본 연구에서는 중다회귀분석을 통해 직무스트레스와 스트레스 대처방식이 직무만족도 를 설명하고 있음을 확인하였다. 이는 초등교사 의 직무만족도에 직무스트레스와 스트레스 대처 방식이 중요한 변인임을 알 수 있다. 후속연구에 서는 이러한 변인들을 가지고 각 변인의 매개효 과나 조절효과를 검증할 수 있는 연구가 필요하 다.

둘째, 본 연구는 부산이라는 특정 지역에 국한 된 초등학교 교사만을 대상으로 실시하였으므로 모든 초등학교 교사들에게 일반화시키기에는 한 계가 있다. 그러므로 후속연구에서는 전국 단위
의 무선표집이 필요할 것이다. 또한 중등학교 교 사를 대상으로 한 연구와 초중등교사를 비교한 연구가 필요할 것이다.

본 연구의 문제를 해결하는 과정에서 확인된 사실을 토대로 초등학교 교사의 직무스트레스와 스트레스 대처방식 및 직무만족도에 관한 정책 입안 시 적용할 수 있는 시사점을 제시해 보면 다음과 같다.

첫째, 직무만족도의 전체뿐만 아니라 직무만족 도의 하위요인인 직무, 보상, 행정지원, 인정지위 에서보상인사가 가장 큰 영향을 미치는 요인임 을 확인할 수 있다. 인간관계에서는 행정체계가 가장 많은 설명력을 가지는 것으로 나타났는데, 각종 사무처리 업무의 폭주와 사무분장으로 인한 교사들의 갈등이 높아 직무만족도의 하위요인인 인간관계에서 만족도가 떨어질 수 있음을 시사한 다. 교육과학기술부와 시도교육청은 교원의 업무 경감을 위해 많은 대책을 마련하여 실시하여 있 으나 여전히 많은 공문처리 등 사무의 폭주로 인 해 학습지도 및 교재연구 시간이 침해 받을 뿐만 아니라 학교업무의 특성상 업무분장의 경계선이 모호한 영역의 공문 처리를 두고 교사 간 갈등, 관리자와 교사 간 갈등이 잦으므로 단위학교 교 사 인원이나 학급수에 따른 시도교육청의 분명한 업무분장 지침이 마련되어야 할 것이다.

둘째, 통제방법은 직무만족도의 하위요인 중 인간관계, 보상, 전문성신장, 행정지원, 인정지위 모두에서 보상.인사에 이어 가장 많은 설명력을 가지는 것을 알 수 있다. 이는 초등교사들이 전 문가와 상의하거나 선배 및 동료교사의 조언을 구하거나 더욱 잘하려고 세심한 계획을 세워 자 신의 발전의 기회로 삼으려는 태도를 갖는 것이 직무만족도의 증진시킬 수 있음을 시사한다. 이 를 위해 학교 단위 혹은 장학지구 단위로 중견교 사와 초임교사들을 연계하여 생활지도, 업무처리, 학습지도 기술 등에 대한 정보를 나누고 자문할 수 있는 멘토링 제도를 운영하는 방안을 마련할 필요가 있다. 
셋째, 전체적으로 초등교사의 직무만족도에 대 한 설명력은 스트레스 대처방식보다는 직무스트 레스가 더 크다는 것을 감안할 때, 보상.인사, 학 교 조직개발, 학교시설 개선, 학습자료 제공, 잡 무경감, 행정체계 및 행정절차 등을 개선하기 위 해 생태체제적 관점(ecological-systematic model) 에서 외부 컨설팅을 받는 방안을 시도교육청 단 위에서 검토할 것을 시사한다.

\section{참고 문헌}

김기석(1994). 직무만족에 영향을 미치는 직무스 트레스 요인에 관한 연구, 박사학위논문, 청주 대학교 대학원.

김봉신(1996). 교사의 직무수행과 갈등 및 스트레 스 해소방안, 석사학위논문, 수원대학교 대학 원.

김윤하(2005). 초등교사의 자기효능감과 사회적지 지 및 직무스트레스와의 관계, 석사학위논문, 공주대학교 교육대학원.

김정휘·고홍화(2003). 교사의 정신 건강과 직무 스트레스. 교육마당 21. 교육인적자원부. 2001. 5. (통권 231호).

김진희(2000). 직무스트레스와 건강상태와의 관계 연구. 석사학위논문, 이화여자대학교 대학원.

류순열(2004). 특수교육교사의 직무만족도 및 관 련성격 변인 탐색, 석사학위논문, 순천대학교 교육대학원.

박영재(2003). 교사 직무 스트레스 수준과 대처방 안, 석사학위논문, 전북대학교 교육대학원.

박청자(1983). 교사 사기에 관한 연구, 석사학위 논문, 이화여자대학교 교육대학원.

박태철(2001). 교사의 직무 스트레스 요인과 그 대처방안에 관한 연구, 석사학위논문, 동아대학 교 교육대학원.

박현진(2003). 고3 담임교사의 직무 스트레스 정 도와 대처방식에 관한 연구, 석사학위논문, 이 화여자대학교 교육대학원.

서대철(2002). 교사의 직무스트레스와 대처방안에 관한 연구, 석사학위논문, 전주대학교 교육대학 원.

성병창(2007). 초임교사 교직 적응을 위한 지원 방안, 수산해양교육연구 19(2), 310 322.
신종학(1995). 직무 스트레스와 직무만족과의 관 계에 관한 연구, 석사학위논문, 동국대학교 경 영대학원.

양영모(2000). 중학교 교사의 직무스트레스 수준 과 성격유형 및 체벌 수준과의 관계, 석사학위 논문, 한국교원대학교 대학원.

여환원(1999). 초·중등교사의 스트레스와 직무만 족도와의 관계, 석사학위논문, 명지대학교 교육 대학원.

연합뉴스, 한국교총 온라인 조사, 2012년 5월 14 일자

오숙희(2006). 초등학교 교사의 직무 스트레스 대 처방식에 대한 분석 연구, 석사학위논문, 서울 교육대학교 교육대학원.

원용준(1997). 초등학교 교사의 스트레스에 관한 연구. 석사학위논문, 동국대학교 교육대학원.

원효헌 · 남인애(2003). 중학교 교사의 교직사회화 단계별 교직의식 및 직무만족도 분석. 수산해 양교육연구 15(2), 145 153.

윤성혜(2007). 교사의 심리적 안녕감과 스트레스 대처방식 및 직무만족도와의 관계, 석사학위논 문, 경성대학교 대학원.

이경화 - 정혜영(2009). 학교조직풍토와 교사의 직 무스트레스의 관계, 수산해양교육연구 21(1), 121 133.

이범국(1999). 초·중등교사의 스트레스와 직무만 족도와의 관계, 석사학위논문, 명지대학교 교육 대학원.

이향란(1992). 교사의 스트레스와 대처방안 연구. 석사학위논문, 고려대학교 교육대학원

이현숙(1993). 초등학교 교사의 직무 스트레스와 직무만족과의 관계. 석사학위논문, 서강대학교 교육대학원.

이현정(2007). 특수교사의 직무만족도에 영향을 미치는 직무특성, 석사학위논문, 경성대 대학 원.

이희영 - 정민상(2007). 비합리적 신념이 교사 소 진에 미치는 영향, 수산해양교육연구 19(3), 467 477.

장연진(2008). 초등학교 교사의 인간관계와 직무 스트레스의 관계. 석사학위논문, 공주교육대학 교 교육대학원.

장한기 - 강경희(2006). 중학교 교사들의 교직문화 와 직무만족, 수산해양교육연구 18(1), 1-10.

장한기·조영주(2006). 교사들의 갈등관리 유형에 따른 직무만족의 차이, 수산해양교육연구 18(3), 
379 389.

전성연(1982). 교원의 직무만족도에 관한 분석적 연구, 서울: 대한교육연합회.

전택수(1992). 초등학교 교사의 직무 스트레스에 대한 연구, 석사학위논문, 단국대학교 교육대학 원.

최인순(2001). 초등학교 교사의 직무 스트레스 지

각 수준과 대처 방법에 관한 연구, 석사학위논 문, 숭실대학교 교육대학원.

홍미순(2002). 초등학교 여교사의 직무스트레스와 그 대응방안에 관한 연구, 석사학위논문, 경상 대학교 교육대학원.

Beehr, T. A., \& Newman, J. E. (1979). Person and organizational strategies for handling job stress: A review of research and option, Personal Psychology, 32, 38.

Bennett, R. (1999). Organizational Behavior, Long Acke, London: Sitran.

Billingsley, B. S., Gersten, R., Gillman, J., Morvant, M. (1995). Working conditions: Administrator support. Paper presented at the National Dissemination Forum on Issues Relating to Special Education Teacher Satisfaction, Retention and Attrition, Washington, DC.

Cichon, D. J., \& Koff, R. H. (1979). The teaching events stress inventory, paper presented at the annual meeting of the American educational research association.

Dworkin, A. G. (1987). Teacher burnout in the public schools: Structural causes and consequences for children, New York: State University of New York Press.

Feitler, F. C., \& Tokar, E. B. (1981). Teacher stress: sources, symptoms and job satisfaction, Paper Presented at the Annual Meeting of the American Education, LA, CA, 13 17.

Ivancevich, J. M., \& Matteson, M. J., \& Prestin, C. (1982). Occupational stress : Type behavior and Physical well being, Academy Management Review, 2, 79 85.

Ivancevich, M. J., \& Metteson, T. M. (1990). Stress and work Glenview: Scott, Foreman. Jackson, S. E. (1983). Participation in decision making, Journal of applied psychology, 68, 3 19.

Kyriacou, C. (1981). Copying actions and occupational stress among school teachers, Research in Education, 24, 147 151.

Kyriacou, C. (1987) Teacher stress and burnout: an international review, Educational Research, 29, 146 152.

Latack, J. C. (1984). Coping with job stress: measures and future directions for scale development. Journal of Applied Psychology, 71(2), 377 385.

Ma, X., \& Macmillan, R. B. (1999). Influences of workplace conditions on teachers' job satisfaction, The Journal of Educational Research, 93(1), 39-47.

Moracco, J., \& McFadden. H. (1980). Counselors role in reducing teacher stress, Unpublished Research Report, Auburn University.

Moracco, J., Danford, D., \& D'arienzo, R. V. (1982). The factorial validity of the teacher occupational stress factor questionnaire, Educational and Psychological Measurement, 42, 132 139.

Ralf, S., \& Suhair, H. (2008). Perceived teacher self-efficacy as a predictor of job stress and burnout: mediation analyses, Applied Psychology, 51(1), 152 171.

Travers, C. J., \& Cooper, C. L. (2006). Teachers Under Pressure: Stress in the Teaching Profession, N.Y.: Routledge.

Wiseman, D. L., Cooner, D. D., \& Knight, S. L. (1999). Becoming a teacher in a field-based setting, Wadsworth Publishing Company.

Yoon, J. S. (2002). An Investigation of Interpersonal Relationships Between Teachers and Students, the School Psychology Research Collaboration Conference.

- 논문접수일 : 2012년 04월 06일

- 심사완료일 : 1차 - 2012년 06월 18일 2차 - 2012년 06월 30일

- 게재확정일 : 2012년 07월 05일 